\title{
Interpreting the Meaning of Loro Blonyo as A Basis for Creation of Intermedia Art Works
}

\author{
Satriana Didiek Isnanta \\ The Fine Art Departement, The Indonesian Institute of Arts in Surakarta, \\ Jl. K.H. Dewantara 19 Surakarta, Central Java, Indonesia \\ Much. Sofwan Zarkasi \\ The Fine Art Departement, The Indonesian Institute of Arts in Surakarta, \\ Jl. K.H. Dewantara 19 Surakarta, Central Java, Indonesia \\ Asmoro Nurhadi Panindias \\ The Fine Art Departement, The Indonesian Institute of Arts in Surakarta, \\ Jl. K.H. Dewantara 19 Surakarta, Central Java, Indonesia
}

\begin{abstract}
This research was designed as an experimental study of intermedia art creation based research by interpreting Loro Blonyo statue as a source of ideas for creating works. Loro Blonyo is a pair of wooden sculptures consisting of statues of woman and man, using the traditional Javanese style of basahan wedding dresses in a sitting position. Broadly, the meaning of Loro Blonyo statue for Javanese people is the unity of the couple as a reflection of Javanese' mind that is harmony and oneness. The meaning of Loro Blonyo statue is then analyzed, elaborated, and reinterpreted as the basis for the creation of intermedia artworks of national identity. The results of the research were concluded and formed as the basis for the concept of intermedia artworks. To create visual language based on local culture, use the concept of art of reinterpretation. The concept of art reinterpretation is to find various alternatives of visual forms from the results of reinterpreting traditional visual arts. This means that the artwork created is the result of the artist's processing in reinterpreting the form or meaning and philosophy of the traditional visual arts and then transferring it into personal style artworks. This study used artistic research methods with the aim of creating space-based intermedia artworks that use visual, motion and sound elements, namely multi-media installation art with a visual form of local culture as a reinforcement of national identity.

Keywords: intermedia art, interdiscipline, experimentation, Loro Blonyo, national identity.

DOI: $10.7176 / \mathrm{ADS} / 78-05$

Publication date: November 30th 2019

\section{Introduction}

The development of fine arts in Indonesia today has historically been inseparable from various global influences that lead to trends in adopting, appreciating, and synthesizing new thoughts conveyed through education, literature, mass media, technology, international relations which all lead to discourse, ideology, markets and visual art practices. This raises the paradox of Indonesian art identity in international art configurations.

To address the conception of art that has roots in Indonesia, alternative concepts for the development of art need to be found. A cultural idiom rooted in ethnic traditions that have become the nation's wealth must be utilized. Art traditions are able to give joy to artistic creativity; as a source of ideas and expression media. Progressive attitudes that require creativity produce cultural products that stand in the present that produce experimental alternative forms. To realize an alternative of cultural product form that is experimental in nature, creative strength is certainly needed.

It can be said that creativity is a keyword in the process of experimentation of works in particular and the development of art in general. With creative thinking, it is possible to discover new things in art practice by exploring local values such as the study of the creation of intermedia art works aimed at creating national personality works with the basic idea of reading the meaning of Loro Blonyo statue.
\end{abstract}




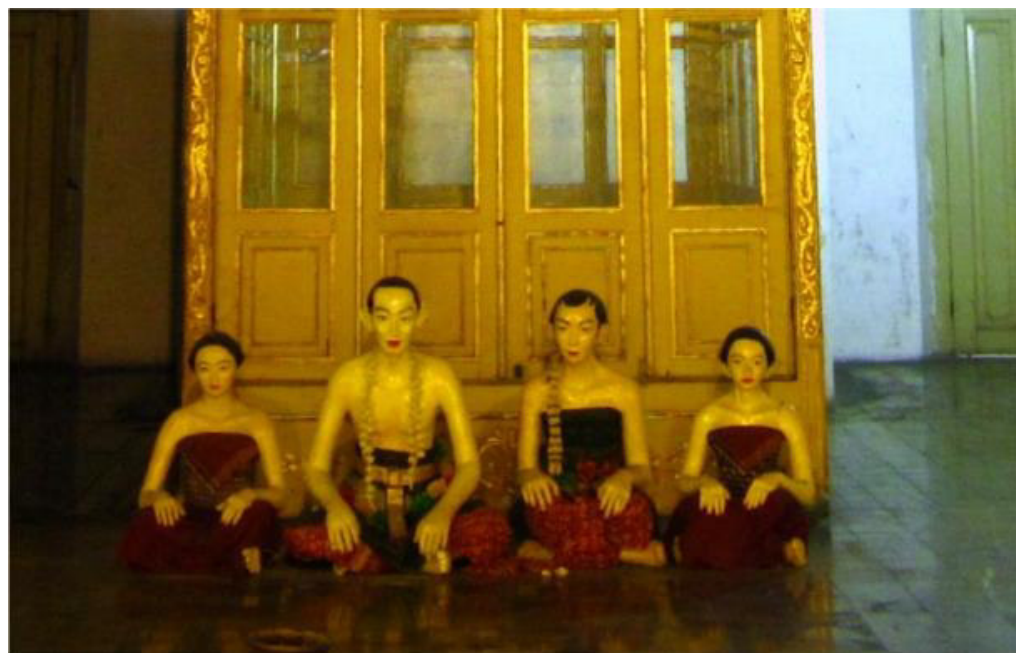

Picture 01. Loro Blonyo statue in the palace Sasono Mulya Keraton Surakarta

(Doc. Aditya Darmasurya, 2012)

This research is important because there are serious conceptual issues that still shackle our art education framework, with sustainable arts colleges placing vocabulary in fine arts faculties based on fine arts category (painting and sculpture) and applied-based arts (wood, metal, and metal crafts from ceramics) on a diametric line. Of course this will have consequences as a barrier to the emergence of new art in the academic space.

Art education institutions, in the most general sense are actually places or formal institutions to educate the birth of professional artists. This demand for professionalism is measured in many ways, one of which is mastery in mindset and mindset. From there various findings in experiments (thinking and practice), case studies, and the emergence of habits in making the commodification of aesthetics or trends in society can continue to be activated.

That is, art colleges not only serve as guardians of existing culture and traditions, but the demands of professionalism and experiment are equally important to be realized. Although the basis of its main interest is limited by conventions, traditions, or agreed rules, convention exploration can still be studied continuously.

Therefore, it is necessary to continue to emphasize efforts to experiment with works, because from this experimental process will be found possibilities for newness in theory, practice and discourse that can indirectly develop existing theories, practices, and art discourse.

In addition, intermedia art is an unconventional and interdisciplinary work of art, which breaks down the boundaries of visual art conventions and also uses unconventional media as well, such as integrating art with other disciplines, especially technology (science). Intermedia art opens the possibility of not only displaying visual aspects but also sound and motion (kinetic).

\subsection{Literature Review}

Nowadays the boundaries of the medium of art are very broad. Works of art are no longer limited to traditional media that were previously used by art maestros who lived in the era of modern art. This also applies to new media available to contemporary artists where the typology of the fine arts medium, as an explanation of the specifications and characteristics of the media used in fine arts, currently provides a much wider choice both for artists directly connected with the social field of art and the public in general. In the typology of the art medium, it is explained that the art media consists of five media, namely traditional media, new media art, dematerialization of art, cross-disciplinary art (intermedia art), and post-media. (Kusmara, 2011: 81)

Intermedia art practices art work as an interdisciplinary process that no longer refers to conventional concepts about the medium of fine arts, especially in the paradigm of fine arts (painting, graphic arts, and sculpture). This is like Kusmara's opinion (2011: 81) which explains that conventional media consists of three types of media consisting of drawing, painting, and sculpture. New media art consists of three media, namely photography, video and digital art, while the cross-disciplinary art (intermedia) includes two types of media in the form of installation art and performance art.

Installation art is a work of art consisting of a combination of various media so as to form a new unity and offer new meaning. Installation art becomes a tangible manifestation of the liberation of fine arts from the classification of painting, graphic art, sculpture, advertisement, and other branches of fine arts, as well as the elimination of ordinary people's views of fine arts into pure art - applied arts, high art - low art, or bound-free art (Ramadhani, 2017: 140).

Installation art according to Mark Rosenthal (2002) in his book entitled "Understanding Installation Art" divides installation art into 2 categories, namely "Filled-Space Installation" and "Site-Specific Installation". 
Filled-space, where the installation work is only as a filler of space (space in architectural and imaginary spaces (open space) and when it is moved to another space the form of the work remains the same as before, whereas Site-specific where the work is always adaptive on the site (space) even to explore the space/site in the work. In this type of work, it is very contextual in space and is a dialogue between the artist and his space and environment, both real space (space in architectural buildings and imaginary spaces (open space).

Performance art is a performance that is presented to the audience. Usually this branch of art is interdisciplinary or involves 2 or more disciplines of art, academic, or scientific. Performance art can occur anywhere anytime, even the public can be part of a work (Merriam-Webster Dictionary, 2008: 873). Performance art is a combination of fine arts with the performing arts of a cross between art exhibitions and theatrical performances. In this case, visual, musical, and motion elements are displayed, but avoid the traditional story line (Ramadhani, 2017: 140).

Looking at the two definitions of installation art and performance art included in intermedia art, it can be divided into two parts, first is space-based artwork (installation art) and time-based art (performance art). This is like the opinion of Mia Maria (2015: 29): Space-based work uses space as one of its constituent elements, for example, installation art. Time-based works are works that have a span of time in the process of presentation, for example, performance art, video art, and interactive art.

After performance art intersects with technology, it finally metamorphoses into multi-media performance. In the development of this performance, not only is the body the medium (although the body remains the main media), but it is also collaborated with media technology to strengthen the message of the artist to be conveyed. Usually explore space and light with the help of a computer/media player whose visual output uses an LCD projector. (Isnanta, 2010: 5)

On the other hand, art which is related to technology and contains visual, motion and sound elements is commonly called multi-media art. "The term multimedia is rooted in theater, not computer. Performances that utilize more than one medium on the stage are often called "multi-media" shows. Multi-media shows include video monitors, synthesized bands, and human art as part of the show!'(Daemon, 1996: 17)

From the description above, the intermedia artwork that will be created later will be in contact with media technology, namely space-based intermedia artwork (multi-media installation art).

Unlike its development with countries that create and produce high media technology and become the ruling state of media technology, Indonesia, known as a technology user country, basically has its own ways and characteristics in managing media technology, including interdisciplinary intermedia art.

The characteristics that tend to prioritize the real function as the main element in the utilization of media technology have led to the birth of aesthetic language that is appropriate to the social culture of the local community. One of them is the study of the creation of intermedia artworks inspired by the meaning of Loro Blonyo statue.

The term Loro Blonyo comes from the word loro meaning two, and blonyo means picture or color, meaning a pair consisting of man and woman embellished with various colors. There are other terms that connect with the title Rara or woman, and also blonyoh which means scrub. The last understanding of the connotation is the love relationship between man and woman, which is associated with marital events. In the broad meaning of the two statues in the unity of the pair is is analogous to a reflection of Javanese mind in harmony and oneness (Prasetyo, 2012: 5).

The rich diversity of Nusantara culture has become an important resource that is believed to have the ability to give birth to the aesthetic language of intermedia art that is spesific, unique, and has a social function that can be applied in society and shared with other countries. Such study on the creation of intermedia artworks will elevate local wisdom by interpreting the meaning of Loro Blonyo statue as the basis for creating intermedia artworks with national personalities.

\subsubsection{Methods}

In creating works, a method is needed to explain the stages of the creation process. The method used in the process of creating art works outlines several steps such as the stages in Dharsono's Artistic Creation (2016). First, research with ethical and emic approaches as the basic for the creation of works, and second, the stages of creation of works contain: experimentation, contemplation, and formation.

\section{Results and Discussion}

Each object is a symbol with a certain meaning. A pair of Loro Blonyo statues are no exception. Loro means a pair and Blonyo means anointed with flower water. Loro Blonyo means bride with a fragrant flower. The statue of the bride symbolizes Dewi Sri and Man symbolizes Raden Sadana (Sulistyo, 2009: 3). Javanese faith in Dewi Sri is inseparable from their agrarian life. Dewi Sri is a fertility goddess who plays an important role in determining the welfare of agrarian societies (farmers). In order to try smoothly, it is necessary to provide a special place in his house to respect the farmers. Mangunwijaya (1992: 108) explains what is meant by Sang Tani is not a person who is a farmer who has a house, but the gods, or specifically Dewi Sri. 
In this way, Loro Blonyo is also associated with the myth of Dewi Sri, who according to the Javanese as the goddess of rice/fertility. Thus, the authors believe that the statue of Loro Blonyo is very close to the lives of Javanese people and has a special position in Javanese agrarian culture (Widayat, 2009: 8). Dewi Sri is respected by Javanese farmers as the goddess of rice, the goddess of happiness, the goddess of fertility and the goddess of household. So close it is sometimes called mbok Sri (Wibowo et al., 1987: 101). Mbok is another word of mother that is widely used in rural Java to greet children to their mothers.

Myth is interpreted as folklore about semi-historical events that explain the problems beginning and end of human life (Haviland, 1993: 98). Myth is basically religious, because it provides a ratio of religious beliefs and practices. The problems discussed in myth are the main problems of human life, such as: where we are from and everything in this world, why we are here, and where we are going. Likewise with the myth of Dewi Sri who is very familiar with Javanese agrarian society. For them, Dewi Sri is an icon as well as an important figure who is very instrumental in determining the outcome later. Thus, it is not strange if in their private home, there is a special place that is used as a place of worship of Dewi Sri. The mythology of Dewi Sri is indeed quite wellknown in Indonesia.

Goddess Sri is considered a 'spirit' that presents joy, happiness, and prosperity. The figure of Dewi Sri is always described as beautiful, able to fly and always has an elegant smile, not only described as a goddess of food, but also as a symbol of beautiful woman, a symbol of the beauty of the earth (F. Widayanto, 2003: 10).

Loro Blonyo is a pair of Javanese bridal statues that are next to one another in a kneeling or standing position. In the daily life of Javanese agrarian society, this statue becomes an important part of the interior elements of one of the architectural building spaces of Javanese traditional houses, called senthong tengah (H.J. Wibowo, -ed-1996: 62-63). This relates to the technique of processing materials (wood) in the process of making Loro Blonyo statue (Prasetyo, 2012. Thus, Loro Blonyo statue from its position can be divided into two, namely sitting and standing Loro Blonyo statues.

The size of Loro Blonyo is varied from the length/height of less than $10 \mathrm{~cm}$ to more than $100 \mathrm{~m}$ for a sitting statue, while for a standing statue it can be up to approximately $170 \mathrm{~cm}$, or sometimes even longer due to an order (Sulistyo, 2009: 5). Based on its general size, Loro Blonyo statue can be grouped into three size groups as follows.

- Large: for sitting position, the size of the Loro Blonyo statue is $1 \mathrm{~m}$, and for the Loro Blonyo statue of standing position, it is $150-170 \mathrm{~cm}$.

- Medium: measuring 50-70 cm high

- Small: 10-20 cm high, generally Loro Blonyo is in a sitting position.

Loro Blonyo statue in its later development has been commodified and its form has been stylized. The form of Loro Blonyo statue which originally referred to the human realist form has been simplified without leaving its original form. This is adjusted to the aesthetics of the mass culture that is developing in society. Fine curved lines (blunt) and bright colors and facial expressions and relaxed body position make Loro Blonyo statue increasingly in demand by the public as an aesthetic element of the interior of their home.

The development of the shape of Loro Blonyo statue has been commodified and the shape has been stylized. The form of Loro Blonyo statue which originally referred to the human realist form has been simplified without leaving its original form. This is adjusted to the aesthetics of the mass culture that is developing in society. Fine curved lines (blunt) and bright colors and facial expressions and relaxed body position make Loro Blonyo statue increasingly in demand by the public as aesthetic element of the interior of their home.

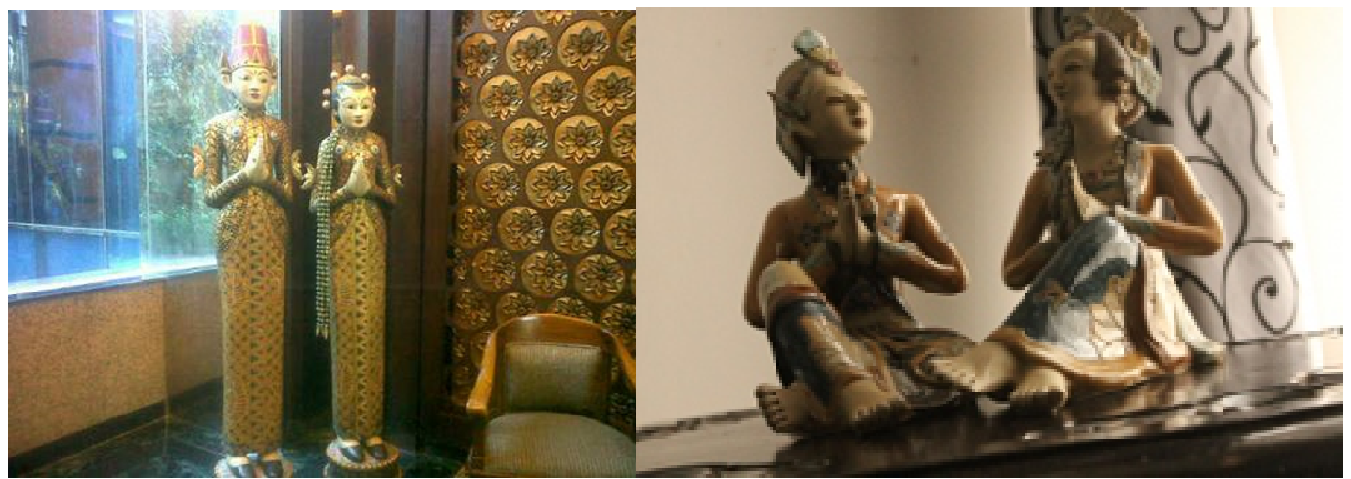

Picture 02 . The form of contemporary loro blonyo figure that becomes an interior decoration (Isnanta, 2019)

From the description above, it can be concluded that the meaning of the Loro Blonyo statue for Javanese people is fertility, happiness, hope and a symbol of the beauty of the universe. Loro Blonyo is a reflection of Javanese thought in harmony and unity. The shape of Loro Blonyo finally has undergone a change, more 
impressed aesthetically with a variety of shapes, sizes and materials. Javanese people see that contemporary Loro Blonyo still considers Loro Blonyo because it is still in the form of two brides. Loro Blonyo statue has become profane, not sacred anymore. The essence of the Loro Blonyo form is a pair of bride, groom and bride.

The results of the initial research then become the basic for the creation of the work. In addition to Loro Blonyo statue, in Javanese culture there is another folklore related to land or earth, namely Sang Hyang Antaboga, god of the earth. This figure is in Javanese wayang story. He is the god of earth guardian. Sang Hyang Antaboga has two forms namely as a human being and when tiwikrama Sang Hyang Antaboga changes its form as a Dragon. Sang Hyang Antaboga is a God who lives under the seventh layer of the earth and resides in Saptapratala which means the seventh layer of the earth. (picture)

Therefore, the main element of this work is Loro Blonyo who is riding a dragon/earth god. This is a representation of the above and below earth guardian. The choice of Sang Hyang Antaboga's form in the form of a dragon is because this form is better known by the Javanese people.

Earth guardian is currently the most relevant to environmental issues. Forest is exploited and deforested for plantation land and industries that use wood as the main material, such as pulp and paper. Reading the history of paper is like reading the history of human civilization. The explosion of print reproduction began in the 15 th century with the creation of printing equipment by Johannes Gutenberg and developed rapidly along with the development of the print industry and mass media. In the information age, mass media has become a major force for the spread of news, science and at the same time become one of the pillars of democracy. When the awareness of the world community on environmental issues strengthens, the use of paper media is in the spotlight, not least in Indonesia. One tree trunk, when processed into pulp and paper only becomes 16 reams. Imagine, how many trees must be felled for the needs of paper every day.

About $70 \%$ of the land area in Indonesia is the National forest area. Indonesia's forests function as the lungs of the world and are considered to significantly affect the world's climate. Apart from being a source of world biodiversity, Indonesia's forests have become a concern to be maintained. As time goes on, Indonesia's forests are increasingly gone. Forests that used to be rich are now increasingly gone. According to the Forest Watch Indonesia report in 2018, in 2013 Indonesia lost \pm 1.1 million hectares of natural forest. This means that every minute three times the football field was lost. Indonesia is experiencing massive deforestation. In the period 2005-2015, Indonesia lost 7 percent of forests (or a total of 1.4 million hectares).

The paradox about the function and benefits of paper with the deforestation process finally gave birth to the work titled, "Paper ...?". The work uses the main aesthetic element in the form of a wedding couple, male and female riding a dragon using rattan. The decision to choose rattan as the main material is based on the flexibility of the characteristics of rattan that can be formed in anything. In addition, in Surakarta there is rattan handicraft industry center which is quite large and has been exported, and therefore the human resources for rattan processing are available and have proven their expertise. Rattan is processed using free-tie techniques to reduce the impression of handicrafts.

After the statue is finished, the next process is to assemble the statue with kinetic mechanics to test its movements and to find out whether the installation technique is perfect or not. To strengthen the concept and metaphor to get to the apresian (art creator), then another aesthetic element is added, namely audiovisual which contains the destruction of forests and newspaper printing machines that refer to the industry with a paper medium. All the aesthetic elements are then assembled into a unity of space-based intermedia artwork in the form of multi-media installation art. 


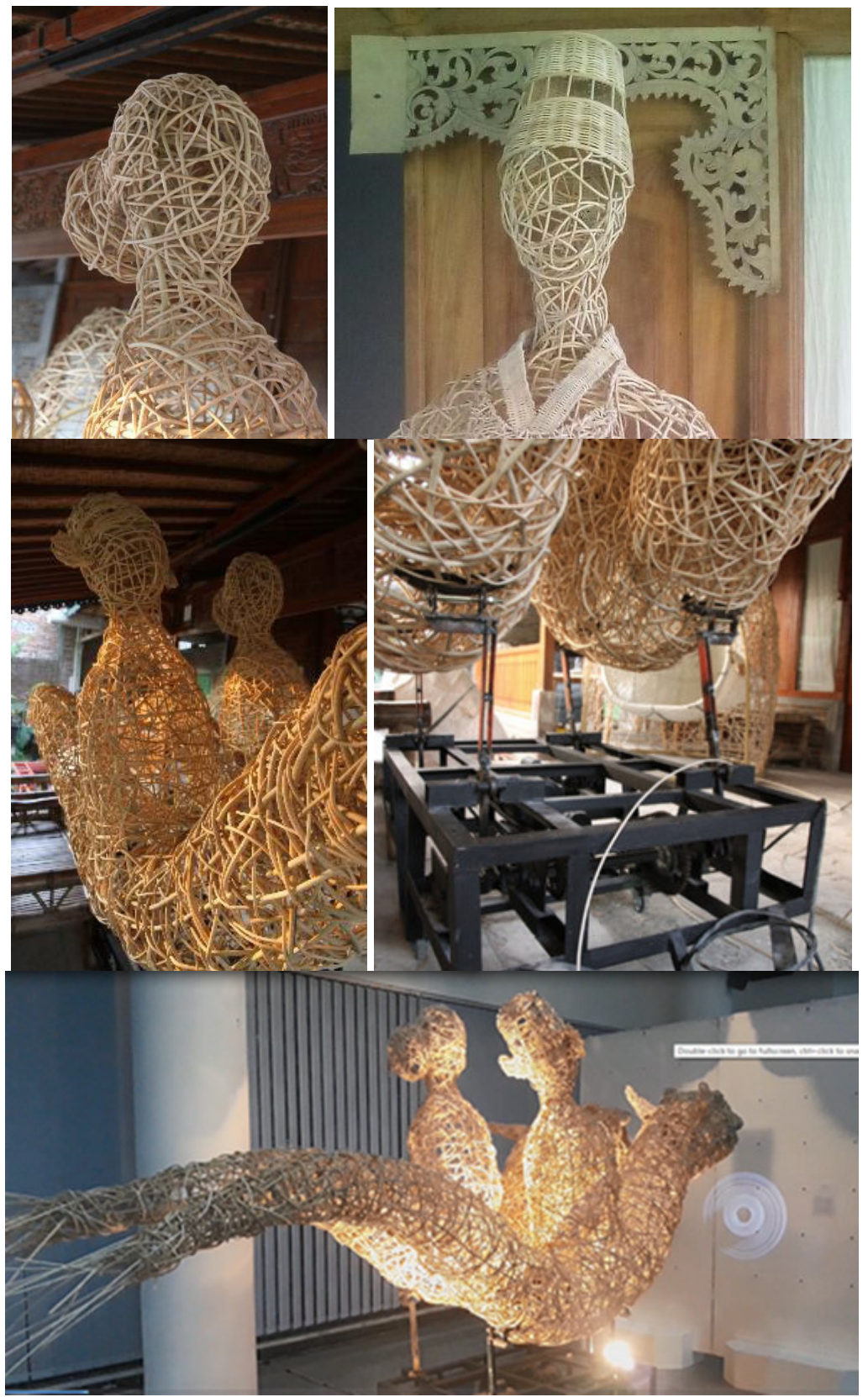

Picture 03.

Rattan loro blonyo statue made using free-tie technique and procces creation

(Zarkasi, 2019)

\section{Conclusion}

In reinterpreting the meaning of Loro Blonyo statue, we must elaborate all the information and abstract it to find the essence of its visual meaning and form. Next, it will be developed into a visual form that suits the visual style of the creator.

Since the era of Sultan Agung (The Greal Sultan) until now, the statue of Loro Blonyo has undergone a change in meaning and form in accordance with the visual style of its creator. The value of Loro Blonyo statue has changed from sacred to profane. The statue which for the Javanese people is a unity of the couple as a reflection of Javanese mind in harmony and oneness has shifted only to an interior aesthetic element.

The process of melting visual forms of intermedia art works of national identity requires a process of studying traditional culture to find the essence of meaning and form. This is important to keep the audience's perception in order to keep capturing the form of figure that is developed still "Loro Blonyo" instead of the others.

The Indonesian nation is a large nation, having a diversity of ethnicities and cultures. Thus, the search for art forms with national identity can be developed from the various cultures that exist in Indonesia, depending on 
the background of the creator.

\section{References}

Daemon, Dean A., Multimedia di Internet, Elekmedia Komputindo, Jakarta, 1996

Dharsono, Sony Kartika, Kreasi Artistik, LPKBN Citra Sains : Surakarta, 2016

Isnanta, Satriana Didiek, "Fusi Seni Dan Teknologi Mendorong Metamorfosis Bentuk Karya Seni Rupa (Studi penciptaan karya Video Performance)," dalam Jurnal Brikolase Vol. 2 No. 2 desember 2010.

Kusmara, Andryanto Rikrik, "Medium Seni dalam Medan Sosial Seni Rupa Kontemporer Indonesia", dalam Disertasi Program Studi Ilmu Seni Rupa dan Desain, Fakultas Seni Rupa dan Desain, Institut Teknologi Bandung, 2011.

Maria, Mia, Berbagi Pengetahuan Tentang Seni Rupa Indonesia, yayasan Jakarta Bienale: Jakarta, 2015

Mangunwijaya, Y.B, Wastu Citra, Jakarta : Penerbit PT Gramedia Pustaka Utama, 1992.

Prasetyo, Ersnathan Budi, "Perkembangan Bentuk Dan Fungsi Patung Loro Blonyo Dalam Masyarakat Di Surakarta," dalam jurnal Dewaruci Vol. 8 No. 1, Desember 2012

Ramadhani , Cadensi Citra, "Penyadaran Berekspresi dalam Estetika Seni Rupa Kontemporer," dalam Seminar Nasional Seni dan Desain: "Membangun Tradisi Inovasi ( Melalui Riset Berbasis Praktik Seni dan Desain)" FBS Unesa, 28 Oktober 2017.

Rosenthal, Mark, Understanding Installation Art: From Duchamp to Holzer, Prestel: Munich, 2002.

Sulistyo, Edy Try dan Jamal Wiwoho, "Studi Simbolisme Dan Identifikasi Seni Patung Loro Blonyo Berbasis "Haki " Sebagai Upaya Melestarikan Konsep Keseimbangan Lingkungan Sosial Budaya Masyarakat Jawa", dalam artikel Hasil Penelitian, Universitas Sebelas Maret Surakarta, 2009.

Wibowo, HJ. dkk., Arsitektur Tradisional Daerah Istimewa Yogyakarta, Yogyakarta : Depdikbud Proyek Inventa-risasi dan Dokumentasi kebudayaan Daerah., 1987.

Widyantoro, Bambang, Pandangan Masyarakat Jawa Kuno Terhadap Lumbung Dan Pemujaan Kepada Dewi Kesuburan, Yogyakarta; Bentang, 1989.

Widayat, Rahmanu, "Krobongan Ruang Sakral Rumah Tradisi Jawa”, dalam Jurnal Dimensi Interior, Vol.2 No. 1 Juni 2004: 1-24. Jurusan Desain Interior, Fakultas Seni dan Desain - Universitas Kristen Petra 